\title{
Students with intellectual disabilities learning fractions: intentional pedagogical actions based on concepts of Vygotsky's defectology
}

\section{Alunos com deficiência intelectual aprendendo frações: ações pedagógicas intencionais baseadas em conceitos da defectologia de Vygotsky} Alumnos con deficiencia intelectual aprendiendo
fracciones: acciones pedagógicas intencionales
basadas en conceptos de la defectología de Vygotsky Bento Selau ${ }^{1}$ Sastria de Paula Rodrigues ${ }^{2}$ Fabiane Costas $^{3}$ Aliciene Cordeiro ${ }^{4}$

DOI: http://dx.doi.org/10.20435/serie-estudos.v25i54.1402

\begin{abstract}
This research aimed to understand the learning process of fractions for two students with intellectual disabilities, collectively with students without any disability. The type of procedure used was interventionist research. There were eighteen subjects in this research, which comprised of Elementary School $6^{\text {th }}$-grade students, two of whom had intellectual disability/focus subjects. The following data collection instruments were used: 10 observations, totaling $8 \mathrm{~h} 20 \mathrm{~m}$, and 10 documentary analysis documents. The results showed that the students with intellectual disabilities learned scientific concepts, which involved the concept of fractions, mainly in relation to the idea of part-whole. The study concluded that the understanding of mathematical content, especially scientific concepts about fractions in the educational process of students with intellectual disabilities, can be effective when applied in processes involving intentional pedagogical actions - based on concepts of Vygotsky's defectology.
\end{abstract}

Keywords: educational psychology; cultural-historical psychology; defectology.

\footnotetext{
${ }^{1}$ Federal University of Pampa (Unipampa), Jaguarão, Rio Grande do Sul, Brazil.

${ }^{2}$ Sul-Rio-Grandense Federal Institute for Science, Education, and Technology (IFSul), Pelotas, Rio Grande do Sul, Brazil.

${ }^{3}$ Federal University of Santa Maria (UFSM), Santa Maria, Rio Grande do Sul, Brazil.

${ }^{4}$ University of the Joinville Region (Univille), Joinville, Santa Catarina, Brazil.
} 
Resumo: Esta pesquisa teve como objetivo compreender o processo de aprendizagem de frações por dois alunos com deficiência intelectual, coletivamente a alunos sem deficiência. O tipo de procedimento utilizado foi a pesquisa intervencionista. Foram dezoito os sujeitos de pesquisa, compostos por alunos do 6o ano do Ensino Fundamental, dois dos quais com deficiência intelectual/sujeitos-foco. Utilizaram-se os seguintes instrumentos de coleta de dados: 10 observações, totalizando 8h20m, e 10 escritos de análise documental. Os resultados mostraram que os alunos com deficiência intelectual aprenderam conceitos científicos que envolviam o conceito de frações, principalmente em relação à ideia de parte-todo. O estudo concluiu que a compreensão do conteúdo matemático, especialmente conceitos científicos sobre frações no processo educacional de alunos com deficiência intelectual, pode ser eficaz quando ocorre em processos que envolvem ações pedagógicas intencionais - com base nos conceitos da defectologia de Vygotsky.

Palavras-chave: psicologia educacional; psicologia histórico-cultural; defectologia.

Resumen: El objetivo de esta investigación es comprender el proceso del aprendizaje de fracciones por parte de dos alumnos con deficiencia intelectual, con relación a los estudiantes sin deficiencia del resto del grupo. El procedimiento utilizado fue la investigación intervencionista. La investigación se realizó tomando en cuenta los dieciocho alumnos de sexto año de la Enseñanza Fundamental, de los cuales dos tienen deficiencia intelectual. Los instrumentos de recolección de datos fueron: diez observaciones, que totalizan $8 \mathrm{~h} 20 \mathrm{~m}$, y diez escritos de análisis documental. Los resultados revelan que los alumnos con deficiencia intelectual aprendieron conceptos científicos, que tenían que ver con el concepto de fracciones, principalmente en relación con la idea de parte-todo. El estudio concluyó que la comprensión del contenido matemático, especialmente de los conceptos científicos sobre fracciones en el proceso educacional de alumnos con deficiencia intelectual, puede ser eficaz cuando es aplicado en procesos que envuelvan acciones pedagógicas intencionales en base a los conceptos de la defectología de Vygotsky.

Palabras clave: psicología educacional; psicología histórico-cultural; defectología.

\section{INTRODUCTION}

The informal dialogues that are established with some teachers of varying types of schools in Brazil about the educational process of students with intellectual disability (ID) (AMERICAN ASSOCIATION OF INTELLECTUAL AND DEVELOPMENTAL DISABILITIES, 2011; HATTON, 2012) often result in the affirmation that these students cannot keep up with the others [without disabilities] in solving the proposed activities in class, which means, they do not have the same learning pace (BEZERRA; ARAUJO, 2011; MUSIS; CARVALHO, 2010; CROCHÍK et al., 2009; RODRIGUES, 2017). As a consequence of this opinion, these teachers hardly ever invest in pedagogical actions for these students. Thus, in a classroom with the other students, ID students, who among the disabled are the majority in Brazil 
(MELETTI; BUENO, 2013), seem already to have succeeded or benefited greatly if they can socialize (which represents a limited comprehension of the possibilities of learning for ID students).

Statements like these can be heard on a daily basis in Brazilian educational institutions and are consistent with a hegemonic view of intellectual disability, "based on the medical model, whose focus is clinical and focused on the difficulties and limitations imposed by organic conditions" (CARNEIRO, 2015, p. 3). These pessimistic conceptions were already raised as issues by Vygotsky (1983b), in the early twentieth century. For this author, [negative] manifestations that qualify the student with ID as someone who only has to live with the other students at school is not only incorrect, but also hinders the potential learning possibilities of the disabled student as they can influence the teaching practices:

Под влиянием пессимистического взгляда на глубоко отсталых детей происходит обычно снижение требований, заведомое сужение, сокращение границ и пределов, которые ставит себе воспитание этих детей. Под влиянием такого взгляда, естественно, возникают минималистские тенденции, стремление свести воспитательные задачи по отношению к этим детям до возможного минимума, ограничиться самым необходимым. [...] [when a person with intellectual disability is deprived of school education, properly organized] теряет в своих возможностях и страдает из-за этого не меньше, но больше, чем нормальный ребенок. [Under the influence of a pessimistic view about severely retarded children, a lowering of demands usually takes place, a knowing narrowing of the boundaries and limits which the educators of these children set for themselves. Under the influence of such a view, minimalist tendencies arise, an attempt to reduce the educational tasks placed before these children to a minimum, to limit them to what is most necessary. [...] [when a person with intellectual disability is deprived of school education, properly organized] loses his/her potential to advance and suffers not less, but more, than a normal child. (VYGOTSKY, 1983b, p. 224).

Vygotsky studied the psychological constitution of people with disabilities and their relation to the world and to the school through their defectology, "moving from practice to theory and vice versa" (DAFERMOS, 2018, p. 27). Stetsenko and Selau (2018) cite that "defectology" is an expression that today seems to be outdated. It was not created by Vygotsky; however, he used it in a theoretical- 
practical original reframing, which was included in all his work (GIEST, 2018; TOOMELA, 2018; COSTAS; SELAU, 2018; PASSERINO; COMA; BALDASSARRI, 2018; BARROCO, 2018; VEGGETTI, 2018; DAFERMOS, 2015; EVANS, 2003; STETSENKO, 2016, 2017; STETSENKO; SELAU, 2018). Taking into account the term defectology, Gindis (2003, p. 200) points out that

[d]efectology is the term that reflects the area of Vygotsky's research and practice that is relevant to contemporary special education and school psychology. [...] Ironically, the negative undertone of the term itself is in no way present in the inspiring and positive attitude of Vygotsky writings. The word defectologia (or defectology in the English transliteration) literally means the study of [the] defect. (emphasis in original).

Although, regrettably, Vygotsky's defectology is not part of the official documents originating from the Brazilian Ministry of Education (COSTAS; SELAU, 2018; BRASIL, 2008), Sannino (2018) and Stetsenko and Selau (2018) emphasize that the in-depth understanding of Vygotsky's defectology is not only useful for researchers who attempt to study the inclusion of the disabled in school; defectology also provides a fundamental basis "to confront and debunk all forms of biological reductionism" (STETSENKO; SELAU, 2018, p. 318).

The present research was carried out considering a selection of some of the vygotskyan premises. Looking at the teacher's responsibility in elaborating teaching strategies that achieve the objective of ID students learning the curricular contents, or more specifically, fractions, this research has been defined, and it was developed with $6^{\text {th }}$-grade Elementary School students, among whom were two female students with ID. The basis of the study was to find an answer to the question: do students with ID learn fractions collectively with students without any disability? [Or, objectively: to understand the learning process of fractions by two students with intellectual disabilities, collectively to students without any disability].

In order to relay the results of this research, there will be presented in the following sections: the research methodological procedures; the findings of the category "Fractions in Scratch: learning obtained via the intervention research" and the data discussion; the final considerations; and references. 


\section{METHODOLOGICAL PROCEDURES}

The type of procedure used was interventionist research (LAITINEN; SANNINO; ENGESTRÖM, 2016; DANIELS, 2016; STETSENKO, 2016; GONZÁLEZ REY; GOULART; BEZERRA, 2016), pedagogical intervention research-type (DAMIANI et al., 2013). Interventional research has been used in a variety of fields: Business Administration (BONNEFOND et al., 2016; QUEROL; JACKSON FILHO; CASSANDRE, 2011), Psychology (SANNINO; SUTTER, 2011), Education (CASTRO, 2014; PINHEIRO, 2014; ROCHEFORT, 2012; CENCl, 2016), among others. Taking a stand on this methodological procedure, Stetsenko (2016, p. s37) states:

[i]n my interpretation, this position implies that methodological tools, strategies and techniques have to be tailored to, and to result, not in the uncovering of facts "as they are" at the present moment and within the given status quo. Rather, it implies intervening with and co-constructing phenomena and processes which we investigated in non-neutral, historically determinate ways in line with the ontological, epistemological and ideological commitments and goals that the researchers deem worthy and take on as guides for action.

The participants of this interventionist study were eighteen students at an Elementary Municipal School in the town of Pelotas, Brazil, with eight boys and ten girls. Their ages ranged from eleven to thirteen years old. The focus group participants were two female students with ID from the same class and were selected according to the following criteria: to be a student with ID, to be enrolled in the $6^{\text {th }}$-grade of Elementary School and to be sent by the teacher for tutoring at the Mathematics and Computer Science Laboratory. All due care was taken regarding research ethics, in all the phases of research and with all the subjects. To protect the ID students' identities, the definitions " $\mathrm{S}+$ number" were used.

The axis of the teaching process to carry out this intervention research was the use of a digital educational game, mediated by the teacher-researcher, with content related to the concept of fractions, called Fractions in Scratch. Scratch is a free software program developed in the Massachusetts Institute of Technology ${ }^{5}$

\footnotetext{
${ }^{5}$ Scratch is a project of the Lifelong Kindergarten Group of the MIT Media Lab. It is available free of charge. The Scratch project received financial support from the following organizations: National Science Foundation, Scratch Foundation, Siegel Family Endowment, Google, LEGO Foundation, Intel, Cartoon Network, Lemann Foundation, MacArthur Foundation. For more information, visit:
} 
(LIFELONG KINDERGARTEN DO MIT MEDIA LAB. SCRATCH SOFTWARE, s.d.) which is a visual programming language and allows the users to engage with their own stories, animations, games, simulators, visual learning environments, music, and arts. The game Fractions in Scratch was created by the researchers and it was carried out for a period of four months. As the software is free, no patent was required.

The intervention research consisted of 10 meetings, each one with a limited time of fifty minutes, which took place once a week from September to December 2016, in the Computer Laboratory of the school, locus of this research, and involved all eighteen students in the class. Each of the 10 meetings adhered in sequence to the following script:

a) Resumption of activities developed during the previous meeting: The objective of this part was to provide thinking on the conceptual approaches developed; it was when students would orally report their experiences in the previous meeting. It was the stage of the process in which the students realized their learning with the help of their teacher (VYGOTSKY, 1982a; BREITENBACH, 2018);

b) Game activity: With the mediation of the researchers (WERTSCH, 2007), the students played games composed of fraction activities. The game consisted of 20 (twenty) screens. On the home screen, there was a greeting and invitation for students to participate in the activity. Subsequently, a menu for the participant choice was presented. Each screen had an activity/exercise to be solved. The feedback occurred through discussions during task execution and synthesis. This feedback consisted of a collective discussion about each exercise, which was coordinated by the teacher. Next, there are some of the screens that make up the game Fractions in Scratch. Picture 1 corresponds to the home screen of the game:

https://scratch.mit.edu/about. Recently, this platform was used in the research of Teixeira, Furini and Caimi (2018). 
Figure 1 - Home screen of the game

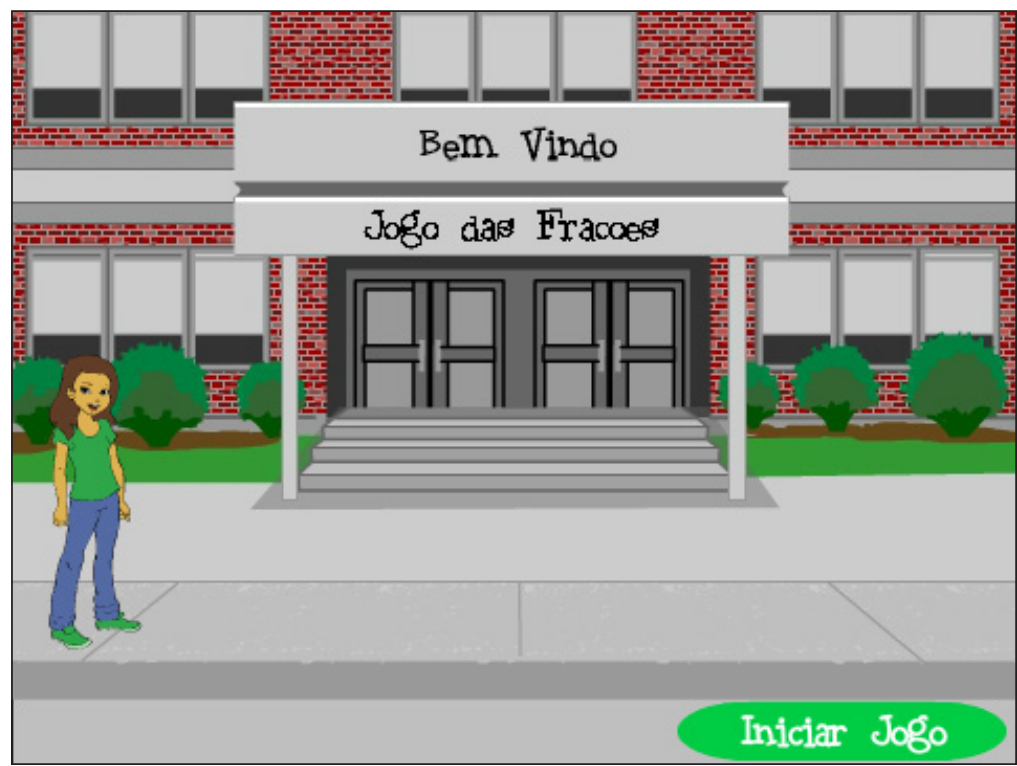

Source: Authors.

After accessing the home screen and interacting with the character, the students were directed to a menu, in which they should choose the game, according to the proposal of the meeting. Picture 2 presents this menu:

Figure 2 - Menu to choose the game

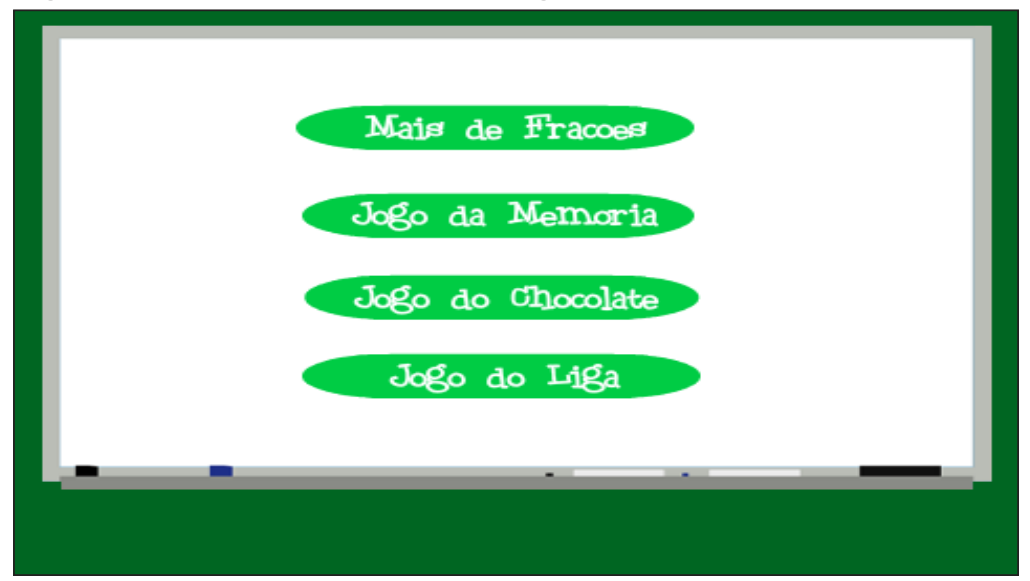

Source: Authors. 
Teaching mediation involved helping students to play, to talk to their classmates and to understand fraction characteristics. With this proposal, an endeavor was made to take into account Vygotsky's theory (VYGOTSKY, 1982a) that the educator should take part in the developmental zone closest to the student, attempting to make advances that do not happen spontaneously. The mediation followed the idea that "development and learning are not in the games themselves, but in what is triggered by the interventions" (DRUZIAN, 2007, p. 69).

c) Report on the activities developed: At this moment, the students gave an oral report about the activities developed on that day to their classmates (VYGOTSKY, 1982a, 1983c; LURIA, 1966, 1971). In this part, mediation between the students and the conceptual approach/fractions was also promoted.

In order to infer the results obtained with this research, two instruments were used for data collection: observation and documentary analysis. The observation (LÜDKE; ANDRÉ, 1986) was performed while playing the game. Video recording was included along with the observation (KOHATSU, 2007) because the meetings were recorded for later transcription. Ten observations were made, which totaled $8 \mathrm{~h} 20 \mathrm{~m}$ of recordings. The documentary analysis (LÜDKE; ANDRÉ, 1986) was performed with diagnostic assessment (two drawings, two qualitative diagnostic evaluations, two school assessments) and post-intervention assessments (two final exams and two descriptive reports). Table 1 summarizes the data collected:

Table 1 - Data collection summary

\begin{tabular}{|c|c|c|c|c|}
\hline Instrument & Number & $\begin{array}{l}\text { Time } \\
\text { length }\end{array}$ & $\begin{array}{l}\text { Application } \\
\text { point }\end{array}$ & $\begin{array}{c}\text { Processing } \\
\text { agent }\end{array}$ \\
\hline Observation & 10 & $8 \mathrm{~h} 20 \mathrm{~m}$ & $\begin{array}{l}\text { During the } \\
\text { interventions }\end{array}$ & Researchers \\
\hline \multicolumn{5}{|l|}{ Documentary analysis } \\
\hline Drawing & 2 & & Diagnostic & Researchers \\
\hline Qualitative diagnostic evaluation & 2 & & Diagnostic & Researchers \\
\hline School assessment & 2 & & Diagnostic & School \\
\hline \multicolumn{5}{|l|}{ Documentary analysis } \\
\hline Final exams & 2 & & $\begin{array}{c}\text { After } \\
\text { intervention }\end{array}$ & Researchers \\
\hline Descriptive reports & 2 & & $\begin{array}{c}\text { After } \\
\text { intervention }\end{array}$ & School \\
\hline
\end{tabular}

Source: Authors. 
The procedure of discursive textual analysis was used for the research data analysis, proposed by Moraes (2003), resulting in the construction of the emerging category "Fractions in Scratch: learning obtained via the intervention research". The methodological process (pedagogical intervention research-type) is outlined below (figure 3):

Figure 3 - Methodological process

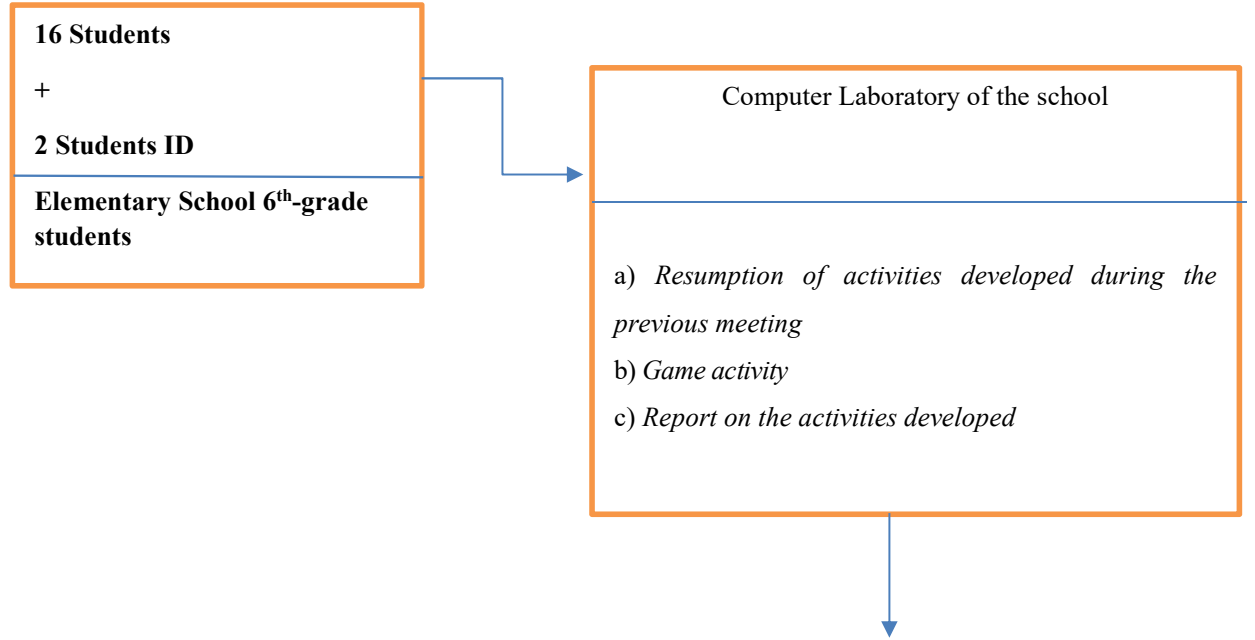

Two instruments were used for data collection: observation and documentary analysis. The observation was performed while playing the game. Video recording was a complement to the observation. Ten observations were made, which totaled $8 \mathrm{~h} 20 \mathrm{~m}$ of recordings.

The documentary analysis was performed with diagnostic assessment ( 2 drawings, 2 qualitative diagnostic evaluations, 2 school assessments) and post-intervention assessments ( 2 final exams and 2 descriptive reports).

The procedure of discursive textual analysis was used for the research data analysis, proposed by Moraes (2003).

Source: Authors.

\section{FINDINGS AND DATA DISCUSSION}

\subsection{What did the students know before?}

In order to plan this intervention research and to implement it and later to understand the effects of the intervention process, it became necessary to have 
prior knowledge about the everyday concepts of fractions that all the students had, especially the focus participants. Anache and Resende (2016) understand that diagnostic assessment is an important element in working with all students, including ID students, in order to elaborate pedagogical action to deal with different situations that arise in the educational context. They state that "the results of the assessment are only valid if they guide the teachers in educational planning" (ANACHE; RESENDE, 2016, p. 573).

Following these formulations, a diagnostic assessment was implemented which aimed to verify the performance of the focus participants in relation to the content of fractions. Fragments from these diagnostic assessments follow (Documentary Analysis):

Scene 1:

Researcher: Let's learn a little more about fractions?

S2: I do not even know what fractions are.

Researcher: Don't know anything? Are you sure?

S2: I know nothing.

S1: Fractions ... hmm ... fractions, fractions, fractions ... Number 1 is a fraction.

Researcher:- Why do you think that number 1 is a fraction?

S1: Because I think so.

S2: I think so too. (Qualitative Diagnostic Assessment)

Scene 2:

Researcher: What are these activities? The numbers here are different, right? S2: They are numbers with a bar.

Researcher: A bar? What are numbers with a bar?

S2: A number with a bar is when there is one on top and one on the bottom. Researcher:- One on top and one on the bottom?

S1: Yes. Write a line and then you write one number on top and then the other on the bottom and that's it.

Researcher: Girls, what does the bar mean?

S1: What did you say? The bar is a bar.

S2: Bar is the line. One number has to stay on top and one on the bottom. Researcher:- But why does one number have to stay on top and another on the bottom?

S1: I do not know. The teacher did it so.

S2: That's the way it is on the board. The teacher did it so. (Qualitative Diagnostic Assessment) 
Realizing that her answer was incomplete, S2, for example, added: "A fraction is a different form of writing/representing calculation" (Qualitative Diagnostic Assessment). According to the fragments, in this same class, S1 and S2 did not even understand the meaning of the word "fraction".

The difficulties of understanding the concept of fractions were also found in the number of correct answers in the students' school assessment (Documental Analysis): out of 15 questions proposed, S1 scored four and S2 6 six. Based on the students' answers, it was observed that the understanding of the concept of fractions was not consolidated (according to Nunes et al. [2005], it is necessary that the students understand that the parts taken from a rectangle, for example, are equal, establishing a relationship between the concept of fractions and the division).

\subsection{Learning fractions based on teacher actions}

After three meetings, there were signs that demonstrated a small understanding about the concept of fractions as a result of the teaching process collectivity implemented, through the collateral method with the digital Fractions game in Scratch. The following transcription is a dialogue that illustrates a situation proposed in the game, in which an attempt was made to work on the ideas of whole and half, through an event commonly experienced in daily life:

Researcher: Let's say $\mathrm{S} 2$ ate a bar of chocolate. What number can I represent this bar of chocolate with? [The student did not understand the activity proposed in the game, so the researcher decided to exemplify the situation using her name].

S2: One, is to eat it all?

Researcher: Yes. And what number will you use to represent it?

S2: One.

Researcher: Very well. And what if instead of eating the whole chocolate, you ate only half?

S2: Only half ... half ... half.

Researcher: Yes. You have the chocolate and you will eat only half. How are you going to show it?

S2: Half, that's not a whole. It's a piece!

Researcher: Right. So, how can you show that?

S2: One-half. [1/2]

Researcher:- Okay! Explain how you solved it?

S2: I got the chocolate and divided it in two. (Observation 3) 
According to Ciscar and García (1988, p. 33), using everyday situations in teaching allows students to recognize mathematics in the world around them, and the teacher's task is to assist them in building the concept involved. In this report, we also observe the attempts to challenge S2 to realize the difference between one whole and one half (NUNES; BRYANT, 1997). Thus, "one" was the answer of S2 to associate it with the whole and "piece" to the other answer, referring to the half.

The understanding of part of a quantity was also evident during the intervention research in the fact that it was understood as fundamentally important in this context. To do so, the following activity was proposed: from an unlimited number of balls of three different colors (orange, blue and green), the students were to place them in baskets, according to the teacher's command. During the activity, the students were asked if they could initially identify the total elements of the set. Once this was achieved, they were asked to identify how many were orange and how many were blue among the components of the set. This moment is described in the fragment below:

Researcher: S2, read the question, please.

S2: "Place the balls in the basket. One quarter of the balls should be blue, three quarters should be orange".

Researcher: Thank you. S1, how many balls do we want in total in the basket? S1: 4.

Researcher: Okay! \$2, how many will be blue?

S2: 1.

Researcher: Why?

S2: You asked S1, how many balls she should have in the basket, and she answered 4.

Researcher: Right! And?

S2: There are 4 balls: 3 are orange. There will be 1 left.

S1: What's left is a fraction. (Observation 4)

It was understood that the situation involving discrete ${ }^{6}$ quantities facilitated the students understanding, leading them to perceive the total amount of elements of the set of balls that should be placed in the basket.

\footnotetext{
${ }^{6}$ Toledo and Toledo (2010) propose that discrete quantities are those in which the measure obtained is always an integer (caps, beans, ...). Continuous quantities are those in which the measure obtained is a number that may not be whole (quantity of water, piece of cloth, tabletop, ...).
} 
During the intervention research, the students were encouraged to talk about their findings. In the following example, the students verbally reported what was done during the meeting:

Researcher: Our time is almost over. Now, I need you to tell me everything we did today. You talk and I write on the board, right? You can start!

S2: Today, we made a toy to guess the future.

S1: The origami oracle and then we played.

S2: We played a game in Scratch of answering questions.

S1: The questions were about a bar of chocolate.

S2: We talked about fractions ... a fraction is a part of a whole.

Researcher: And what else?

S2: There's more, but I can't tell.

Researcher:- What about you S1, what else can you say?

S1: That fractions divide.

Researcher:- Do you want to add anything else?

S2: No.

S1: No. (Observation 5)

It is possible to see that the students struggled in doing what was asked and that they did not present in their description elements that indicated awareness about the process experienced or that learning had taken place. During the intervening process, this situation changed: this moment contemplated the expectation, which consisted in observing, through the narrative carried out by the students, if a restructuring of the relationships was taking place in the intrapsychological framework as those which occur in the interpsychological framework. The following fragment illustrates this situation:

Researcher: Let's report our work today?

S1: All right.

Researcher: Who starts?

S2: Me.

Researcher: You can start.

S2: We played the race of fractions game.

Researcher: Right. And what else?

S1: We saw that in the fraction there are two numbers separated by a line.

S2: The numerator and the ...

S1: Denominator.

S2: The denominator is the number below the line. The number above the line is called the numerator. 
S1: The numerator indicates how many parts have been taken.

Researcher: From where?

S1: From the whole.

S2: The denominator indicates in how many equal parts it was divided

Researcher: Then the terms of the fraction are: the numerator and the denominator.

S2: Yeah.

S1: Teacher, let's name them correctly now.

Researcher: Correctly? Now there won't be a top number and bottom number anymore.

S1: No. Now it's going to be numerator and denominator. (Observation 7)

We can observe the students' evolution because the synthesis they made lead to the understanding of the terms that compose a fraction as well as their meanings.

The content of the seventh meeting was addition with fractions, involving, besides the explanation, routine activities. During the explanation, it was pointed out that there are different ways of proposing and performing an addition. It was requested that a way be worked out of accomplishing the task in groups in which everyone understood the process and no longer added up all the terms. The fragment below shows the synthesis formulated:

S2: When I have to add fractions, I look at the terms. If the denominator is equal, I only count the numerator.

S1: If the terms are different, I have to remember.

Researcher:- I do not understand! Say it again.

S2: If the denominators are the same, I only count, sum up, the numerators.

S1: Yeah! It only applies if the denominators are the same. (Observation 7)

The ID students said that there is a rule in the process of adding fractions. This rule is an exception to spontaneous knowledge, therefore, it can only be learned in school. This intervention procedure, which was the only subject that was working with the concepts of fractions, is a scientific concept.

The aspects that could have contributed to the learning of the ID students within the collectivity were also observed. Vygotsky (1983d) has drawn attention to the fact that the higher psychological functions, which both disabled children and children considered normal, have a social origin, both in phylogenesis and also in ontogenesis. Vygotsky points out that 
Каждая высшая психическая функция появляется в процессе развития поведения дважды: сначала как функция коллективного поведения, как форма сотрудничества или взаимодействия, как средство социального приспособления, т. е. как категория интерпсихологическая, а затем вторично как способ индивидуального поведения ребенка, как средство личного приспособления, как внутренний процесс поведения, т. е. как категория интрапсихологическая. [Each higher mental function appears twice in the process of the development of behavior: first, as a function of collective behavior, as a form of collaboration or interaction, as a way of social adaptation, i.e., as inter-psychological category; and, secondly, as a way of individual child behavior, as a means of personal adaptation, as an inner process of behavior, i.e., as intra-psychological category]. (VYGOTSKY, 1983d, p. 197).

The understanding expressed by Vygotsky has an influence on the way the teacher plans and implements the practice of the teaching process in the classroom (SANNINO; SUTTER, 2011). The collective form of teaching cannot be represented only by the grouping of students without planning: collective forms of teaching take place to the extent that there is collaborative work among students and between them and the teacher. In the situation transcribed below, it is possible to observe that the activity performed in pairs consisted of associating the graphic representation of a fraction with its numerical representation; S1 partner and a classmate [who has a level of development superior to S1] realized her difficulty in accomplishing the task and offered to help her:

S1: I don't know.

Classmate: I'll help you.

S1: It's okay.

Classmate: First, you're going to count how many pieces are in the whole figure.

S1: Right. One, two, three, four, five, six.

Classmate: Did you count?

S1: Yes.

Classmate: Now you have to see how many pieces are painted, colored.

S1: One, two, three.

Classmate: Then you have to put them together.

S1: Together?

Classmate: The drawing with the number. Look here!

S1: I'll try ... I did it! (Note 6) 
The following excerpt is an example of a situation that portrays the value of interactions in the learning process, now starting from the ID student:

S1: I don't get it. I can't fit them in.

S2: Come on, S1. Look how I do it. You have to drag them to put them together.

S1: Yes.

S2: Drag. Count how many pieces there are. Then you count how many are painted.

Researcher: And then?

S1: Do I have to look for the number to put them together?

Researcher:- Number ${ }^{7}$ or fraction ${ }^{8}$ ?

S1: Find the fraction number. (Observation 4)

In this brief report, it was observed that there are two people assisting student S1 (teacher and S2, who is the other student with ID). The participation of these two people in the relationship with S1 was fundamental in motivating her to accomplish the task. It should be noted that the zone of proximal development was created in this triadic relationship, triggered by the teacher.

The evaluation of the learning process is completed with the presentation of the data referring to the new "final assessment" and "descriptive report" (Documental Analysis). In the end, in the final assessment [Documentary Analysis] S1 scored 10 and S2 scored 13 correct answers out of 15 [in the assessment given before the intervention research, S1 student scored 4 and S2 6 out of 15 questions]. The descriptive report (Documental Analysis) of the third quarter also changed: "Regarding the content of fractions, and rational numbers, [S1] seems to have understood the basic concepts, which is fundamental for understanding this numerical set" (Descriptive Report S1); "S2 was able to understand the basic notions regarding this numerical set, which will help her to learn contents of this set" (Descriptive Report S2). The results showed an evolution in the students' learning process, regarding the concept of fractions.

\footnotetext{
${ }^{7}$ Number is a mathematical concept to represent measure, order or quantity. Order numbers are called ordinals and quantity ones are called cardinal numbers. In mathematics, numbers are classified as natural, integer, rational and real (BRASIL, 1998).

${ }^{8}$ Fraction belongs to the set of rational numbers. This set can be presented as a fractional or decimal representation (BRASIL, 1998).
} 
Table 2 - Application of the "final exam" and "descriptive report"

\begin{tabular}{|c|c|c|c|c|c|c|}
\hline Instrument & Subject & $\begin{array}{l}\text { Agent } \\
\text { Devisor }\end{array}$ & $\begin{array}{c}\text { Point of } \\
\text { application }\end{array}$ & $\begin{array}{l}\text { Number of } \\
\text { right answers } \\
\text { /number of } \\
\text { questions }\end{array}$ & $\begin{array}{c}\text { Point of } \\
\text { application }\end{array}$ & $\begin{array}{c}\text { Number } \\
\text { of right } \\
\text { answers }\end{array}$ \\
\hline $\begin{array}{l}\text { Documentary } \\
\text { analysis }\end{array}$ & S1 & Researchers & Diagnostic & $4 / 15$ & $\begin{array}{c}\text { After the } \\
\text { intervention }\end{array}$ & $10 / 15$ \\
\hline $\begin{array}{l}\text { Documentary } \\
\text { analysis }\end{array}$ & S2 & Researchers & Diagnostic & $6 / 15$ & $\begin{array}{c}\text { After the } \\
\text { intervention }\end{array}$ & $13 / 15$ \\
\hline $\begin{array}{l}\text { Descriptive } \\
\text { report }\end{array}$ & S1 & School & & & $\begin{array}{c}\text { After the } \\
\text { intervention }\end{array}$ & ' 1 ' \\
\hline $\begin{array}{l}\text { Descriptive } \\
\text { report }\end{array}$ & S2 & School & & & $\begin{array}{l}\text { After the } \\
\text { intervention }\end{array}$ & '2' \\
\hline \multicolumn{7}{|c|}{$\begin{array}{l}\text { 1. "Regarding the content of fractions and rational numbers, [S1] seems to have understood the basic } \\
\text { concepts, which is fundamental for understanding this numerical set" }\end{array}$} \\
\hline \multicolumn{7}{|c|}{$\begin{array}{l}\text { 2. "S2 was able to understand the basic notions referring to this numerical set, which will help her to } \\
\text { learn other contents of this set" }\end{array}$} \\
\hline
\end{tabular}

Source: Authors.

\subsection{Relating planning decisions and some results}

The aspects that helped in the theoretical decisions to organize the teaching process in interventionist research became clear from the data presented: first, it was understood that people [students] need to think mathematically about everyday situations. This decision involved planning the classes, as described. It is important to highlight that it is not sufficient to only include everyday situations for teaching fractions, or in other words, just learning procedures is not enough for students with ID: "it is necessary to turn these procedures into thinking tools" (NUNES; BRYANT, 1997, p. 31). The subject needs to access new ways of thinking, in other words "learn new conventional systems of representation" (NUNES; BRYANT, 1997, p. 32), enabling the connection with the knowledge already acquired with new situations. Thus, still in the light of the cited authors:

[...] the child's thinking will be expanded through his/her attempts to struggle with new types of invariants. In this case, he/she may use their own symbols and features for some time before being asked to use conventional forms of representation. The conceptual development in mathematics, therefore, is not equivalent to the mastery of a list of procedures, as some approaches 
to curriculum development have assumed in the past. Progress can come from understanding new invariants, from the ability to learn new forms of mathematical representation, and from connecting old ways to new situations that will enrich the child with meaning. (NUNES; BRYANT, 1997, p. 32).

The teaching of rational numbers (fractional representation) is formally initiated between the 4th and 5 th grades of elementary school through basic dayto-day ideas such as division of pizzas, cakes, and chocolate (whole representation) and activities involving the joining of the parts (insert idea/concept of half or $1 / 2$ ). The purpose of the study of fractional numbers is the expansion of the students' mathematical language because the numerical set they know up to this moment (natural numbers) can no longer solve present situations within the school context and in everyday life. Pereira (2011, p. 12) explains that fractions "were created to represent a part or parts of a whole that were divided into equal parts". The fraction thus refers to an "all-reference", which can be taken as a collection of anything.

Pereira (2011) warns that there are different meanings for the concept of fractions: "for the same meaning, there are different resolution strategies used by students and the way of teaching the concept of fractions used in schools gives privilege to some meanings, as part-whole and multiplicative operator, to the detriment of others" (PEREIRA, 2011, p. 12). For this reason, in teaching of fractions, it is important to investigate before the teaching process the students' spontaneous concepts (what is the significance of the students' previous experiences in their lives - in which places they use them and in what forms they are represented - see ESTADO DO RIO GRANDE DO SUL, 2009). According to Pereira (2011, p. 14),

[...] the teacher must create learning situations that provide the development of mathematical thinking, logical reasoning, the appropriation of mathematical language and the understanding of the world around them, through the application of new teaching methods and the use of new pedagogical practices.

The second aspect considered in this research was the following: we supported the idea that the ID students, who were participants of this research, presented all the requirements for the development of abstract thinking, and of 
the higher psychological functions through the learning of a mathematical concept, particularly fractions. This is a fundamental comprehension, which must lead the teaching work since knowing the students diagnosis might not be a reason for labeling them. Vygotsky (1983f, р. 231) says "[н]и одна из интеллектуальных способностей не может считаться вполне отсутствующей у этих детей” ["not a single intellectual aptitude can be considered as altogether absent in these children"]. Vygotsky observed some students who had profound ID who turned out to be capable of rational action (VYGOTSKY, 1983c); in some cases, it has also been shown that "процессах психического насыщения у умственно отсталых детей в возрасте 8-11 лет не наблюдается никаких существенных отличий от нормальных детей в скорости насыщения" ["no essential differences in the speed of saturation can be observed during the process of psychological saturation between mentally retarded children at the age of eight to twelve years and for normal children"] (VYGOTSKY, 1983f, p. 235). Therefore, pessimistic and stigmatizing understandings about the abilities of the students with ID interfere in the class planning and the way they are challenged and as a result, in the goals set for their schooling processes.

The third fundamental aspect is that the teaching proposal [so the game denominated Fractions in Scratch was used] followed the notion of collateral pathways, proposed by Vygotsky (1983a). It is important for the teacher to consider that some contents will be learned by students with disabilities through other ways different from those used for the so-called typically developing children. Vygotsky (1983a) draws attention to the fact that collateral pathways, understood as paths or cultural resources that allow the accomplishment of a task and have a significant pedagogical and creative character for the child, should be considered. Vygotsky (1983a) states that the cultural development in a child's conduct is not necessarily related to an organic function. In such a comprehension, Vygotsky states that human-cultural development occurs by collateral pathways, as explicitly stated:

[...] в процессе культурного развития у ребенка происходит замещение одних функций другими, прокладывание обходных путей, и это открывает перед нами совершенно новые возможности в развитии ненормального ребенка. Если такой ребенок не может достигнуть чегонибудь прямым путем, то развитие обходных путей становится основой 
его компенсации. Ребенок начинает на окольных путях добиваться того, чего он не мог достигнуть прямо. Замещение функций - действительно основа всего культурного развития ненормального ребенка [...]. [[...] in the process of cultural development, there is a replacement of some functions in the child by others, a construction of detours, and this opens before us completely new possibilities in the development of the abnormal child. If such a child cannot attain something directly, then the development of detours becomes the basis for compensation. The child begins to attain in roundabout ways what he could not attain directly. Replacement of functions is actually the basis of all cultural development of the abnormal child [...]]. (VYGOTSKY, 1983a, p. 147-8.)

The importance is clear, therefore, for teachers to develop distinguished pedagogical strategies that enable the development of scientific concepts among students with ID.

The fourth aspect can be found in Vygotsky (1982a) and Luria (1966, 1971), who draws attention to the fact that the spoken word is the mediator of consciousness. All the students, therefore, were made to speak as much as possible in the course of the lessons. Castro, Damiani and Selau (2016, s68-s9) explain this notion, from the following:

From a historical-cultural point of view, it is through words, through the enunciations of others, that we act voluntarily and consciously. We become responsible for our own conduct. But how does it happen? The word, as a sign and epistemologically based on historical and dialectical materialism, duplicates the world in our minds. It encodes experiences and meanings and allows us to become aware of them. Through the word, in human sociability, we develop our consciousness, the matrix of our thinking.

For Vygotsky (1983c), the 'possible' inability of the ID student in terms of abstraction is much more due to the lack of cultural interference as a consequence of primitivism in his/her life than to the primary derivation of the disability itself: "Его неспособность к высшим формам, абстрактного мышления не есть прямое следствие его интеллектуального [...] Он лишь не овладел словом как орудием абстрактного мышления: эта неспособность есть следствие и симптом его примитивности, но не его слабоумия" ["His inadequacy for higher forms of abstract thought is not a direct result of an intellectual defect [...] He simply has not mastered the use of words as tools for abstract thinking: this incapacity is a result and a symptom of his primitivism, but not of his mental 
retardation"] (VYGOTSKY, 1983c, p. 28). Based on the Vygotskyan studies, Breitenbach (2018) points out that

[f]or the process of cultural development, it is necessary for the child [with ID] to be able to use the language, the psychological-cultural tools, and the natural forms of the psychological functions to develop the higher psychological functions. In this way, it is not only the development of functions that will differentiate a more developed child from a less developed one but also his/her cultural equipment and the way he/she uses it.

It is worth noting that all the students, including those with ID, were always encouraged to speak. Although the student's speech about the content studied is a hint that the processes of mental development are going well, the dialogue between teacher and students is also a fundamental element. Wertsch (2007) draws attention to the fact that mediation of Vygotsky can be understood, fundamentally, as explicit and implicit mediation. Explicit mediation can be exemplified as one that shows the intervention as a whole (didactic decisions, social organization of teaching, definition by virtual play, classroom location), and one which is of the fundamental elements as a process of double stimulation; but implicit mediation, more difficult to comprehend, involves semiotic relations in that context (which defines the importance of the teacher as being the person best prepared for the job).

The fifth consideration can be found in the text $К$ Вопросу О Компенсаторных Процессах В Развитии Умственно Отсталого Ребенка [Compensatory Processes in the Development of the Retarded Child], Vygotsky (1983e) presents some principles of the compensatory development of ID that were fundamental for the planning of this research: the principle of the substitution of functions, common to all children, had priority importance: in other words, none of the psychological functions is performed in only one way, but each of them is done in different ways (see TOOMELA, 2016); the principle of collectivity as a factor of development of the higher psychological functions of the normal child and ID, to which Vygotsky draws attention, indicate that mental functions first appear as a form of collaboration or interaction and, secondly, as an internal process of conduct; the relationship between the higher psychological functions are formed differently from those which manifest in the normal child: 
Эта сфера психологического развития, изменение межфункциональных связей и отношений, изменение внутренней структуры психологической системы есть главнейшая сфера приложения высших компенсаторных процессов складывающейся личности. Моторные связи и межфункциональные отношения характеризуют не столько сами функции, сколько то, каким образом эти функции приведены кединству. [This sphere of psychological development, the change in interfunctional connections and relationships, the change in the internal structure of the psychological system, is the most important area for the operation of compensatory processes in forming personality. The functions themselves do not determine the motor connections and interfunctional relationships as much as does the way in which these functions are brought into unity]. (VYGOTSKY, 1983e, p. 126-7).

Finally, the author highlights affection, which encourages the child to overcome obstacles. The affection that the teacher gives to the student "они приводят к обходному пути развития" ["that will lead to a roundabout path of development"] (VYGOTSKY, 1983e, p. 127).

\section{FINAL CONSIDERATIONS}

Finally, what can we say about the question do students with ID learn fractions collectively with students without any disability? The analysis of the data collected led to the conclusion that one of the fundamental elements observed for the learning of fractions by ID students refers to the work of the teacher. The teacher's mediation work, as an intentional, conscious pedagogical action based on the theory underlying his/her actions - Vygotsky's defectology -, is the aspect that creates the best conditions for the students' learning in a group. Based on the presented analyzes, the grouping that involved students with and without difficulty in the regular school classroom, without the correct intervention of the teacher, was insufficient for children to learn fractions.

This result is very important because the proposal of inclusive education in Brazil suffers from propositions, such as those advocated by Mantoan (2017, p. 45), who apparently believe that the teacher only has to bear the presence of the disabled ones in class, as she cites:

In this educational perspective, there is no place for teacher mediation as this is an affirmation of the intelligence hierarchy that sustains the control, 
the conduction, and the superiority of the mediator, having nothing to do with the process of creative construction of knowledge and of disability as an attribute fixed in the person, which wholly defines him/her. (MANTOAN, 2017, p. 45, emphasis added).

Brazilian teachers or psychologists who take ideas such as this to support inclusive education can only reduce this proposal (due to its empty theoretical foundation) and make it widely questioned or denied by parents (who believe in a special school exclusion as the only way of schooling for the child with ID) and to weaken the action of Pedagogy in collaboration with Special Education. This ends up being inpractical (a fundamental basis for the path of a Marxist Psychology and Pedagogy, defended by Vygotsky (1982b) in "Исторический Смысл Психологического Кризиса ["The Historical Meaning of the Crisis in Psychology"]. By questioning Mantoan (2017), Breitenbach (2018, p. 143) argues that " $[t]$ o deny the need for teacher mediation, we limit the possibility of student learning, especially those with some intellectual disability, forgetting one of the Vygotskyan principles [...], which foresee the need for special means of education for people with disabilities".

Nonsensical statements such as Mantoan (2017) not only demonstrate incredible ingenuity but also do not understand the fundamental task of the teacher, as a link to reach the zone of proximal development of the student:

Учитель, работая с учеником над темой, объяснял, сообщал знания, спрашивал, исправлял, заставлял самого ученика объяснять. Вся эта работа над понятиями, весь процесс их образования прорабатывался ребенком в сотрудничестве со взрослым, в процессе обучения. И когда ребенок сейчас решает задачу, чего она требует от него? Умения по подражанию, с помощью учителя решить эту задачу, несмотря на то что в момент решения мы не имеем актуальной ситуации и сотрудничества. лежит в прошлом. Ребенок должен на этот раз самостоятельно воспользоваться результатами прежнего сотрудничества. [The teacher, working with the school child on a given question, explained, informed, inquired, corrected, and forced the child himself to explain. All this work on concepts, the entire process of their formation, was worked out by the child in collaboration with the adult in instruction. Now, when the child solves a problem, what does it requires of him/her? It requires the ability to imitate and solve the problem with the help of teacher even though we do not have an actual situation of collaboration at this moment. The situation lies in the past. Here, the child 
must make independent use of the results of that earlier collaboration]. (VYGOTSKY, 1982a, p. 257).

The research has highlighted the relevance of the teachers' work, wich is understood as essential for strengthening the working conditions so that the teachers can plan their educational activities, basing them on scientific knowledge. This is therefore included in the political agenda, which, though not the focus of this work, can be inserted in discussions in the field of Educational Psychology.

According to the observations and the interventions made, it seems that the sources of development of the psychological processes are always social. Thus, it can be inferred that the experiences provided through the activities enabled student-student/teacher-researcher-student interactions, which demonstrated significant elements for the learning process. However, it is necessary to further develop this type of study to be able to verify the acquired extent of knowledge as well as its effective generalizations in different places and times.

\section{Funding}

This study was financed in part by the Coordenação de Aperfeiçoamento de Pessoal de Nível Superior - Brazil (CAPES) - Finance Code 001.

National Council for Scientific and Technological Development - CNPq.

\section{Acknowledgment}

The authors would like to thank: Professor Aaro Toomela (Sepamäe Academy of Advanced Thought) and Marta Pozzobon (Federal University of Pampa) for their valuable comments and suggestions for improving this article; А. Я. Савицкая and О. Ф. Савицкий, who provided help with Russian language; Marta Teixeira da Silva, Philip de Lacy White, Daniel Mc Redmond, and Elen Karoline Melo de Oliveira who provided help with English language.

\section{REFERENCES}

AMERICAN ASSOCIATION OF INTELLECTUAL AND DEVELOPMENTAL DISABILITIES. Discapacidad intelectual: definición, clasificación y sistemas de apoyo. 11. ed. Madrid: Alianza, 2011. 
ANACHE, A. A.; RESENDE, D. A. R. Caracterização da avaliação da aprendizagem nas salas de recursos multifuncionais para alunos com deficiência intelectual. Revista Brasileira de Educação, Rio de Janeiro, v. 21, n. 66, p. 569-91, July/Sept. 2016. DOI: http://dx.doi. org/10.1590/S1413-24782016216630

BARROCO, S. Vygotski's theories on Defectology: contributions to the special education of the 21st century. Educação, Porto Alegre, v. 41, n. 3, p. 374-84, Sept./Dec. 2018. DOI: http://dx.doi.org/10.15448/1981-2582.2018.3.31826

BEZERRA, G. F.; ARAUJO, D. A. C. De volta à teoria da curvatura da vara: a deficiência intelectual na escola inclusiva. Educação em Revista, Belo Horizonte, v. 27, n. 2, p. 277302, ago. 2011. DOI: http://dx.doi.org/10.1590/S0102-46982011000200013

BONNEFOND, J.-Y.; BONNEMAIN, A.; FONTES, F. F.; CLOT, Y. To institute conflictive cooperation on the quality of work. Educação, Porto Alegre, v. 39, n. esp. (supl.), p. s42-s53, Dec. 2016. DOI: http://dx.doi.org/10.15448/1981-2582.2016.s.24326

BRASIL. Parâmetros Curriculares Nacionais: Matemática. Brasília: MEC/SEF, 1998. Available at: http://portal.mec.gov.br/seb/arquivos/pdf/matematica.pdf. Access on: 14 Apr. 2020.

BRASIL. Política Nacional de Educação Especial na Perspectiva da Educação Inclusiva. Brasília: MEC: SEESP, 2008. Available at: http://portal.mec.gov.br/index.php?option=com_ docman\&view=download\&alias=16690-politica-nacional-de-educacao-especial-naperspectiva-da-educacao-inclusiva-05122014\&Itemid=30192. Access on: 14 Apr. 2020.

BREITENBACH, F. V. A aprendizagem do estudante com deficiência intelectual na Educação Superior: obstáculos e possibilidades. 2018. 250f. Thesis (Doctorate Degree in Education) - Federal University of Santa Maria (UFSM), Santa Maria, RS, 2018. Available at: https://sucupira.capes.gov.br/sucupira/public/consultas/coleta/trabalhoConclusao/ viewTrabalhoConclusao.jsf?popup=true\&id_trabalho=6389650. Access on: 14 Apr. 2020.

CARNEIRO, M. S. C. A deficiência intelectual como produção social: reflexões a partir da abordagem histórico-cultural. In: REUNIÃO NACIONAL DA ANPED, 37., 2015, Florianópolis, SC. Anais [...]. Florianópolis: ANPEd, 2015. p. 1-16. Available at: http://37reuniao.anped. org.br/wp-content/uploads/2015/02/Trabalho-GT15-4079.pdf. Access on: 14 Apr. 2020.

CASTRO, R. F. A expressão escrita de acadêmicas de um curso de pedagogia a distância: uma intervenção histórico-cultural. 2014. 239f. Thesis (Doctorate Degree in Education) Federal University of Pelotas (UFPel), Pelotas, RS, 2014. Available at: https://sucupira.capes. gov.br/sucupira/public/consultas/coleta/trabalhoConclusao/viewTrabalhoConclusao. jsf?popup=true\&id_trabalho=1333780. Access on: 14 Apr. 2020. 
CASTRO, R. F.; DAMIANI, M. F.; SELAU, B. Consciência e controle: uma intervenção histórico-cultural sobre a escrita de acadêmicas de Pedagogia a distância. Educação, Porto Alegre, v. 39, n. esp. (supl.), p. s66-s75, Dec. 2016. DOI: http://dx.doi. org/10.15448/1981-2582.2016.s.24259

CENCI, A. "Inclusão é uma utopia": possibilidades e limites para a inclusão nos anos finais do ensino fundamental - intervenção e interpretação a partir da Teoria Histórico-Cultural da Atividade. 2016. 336f. Thesis (Doctorate Degree in Education) - Federal University of Pelotas (UFPel), Pelotas, RS, 2016. Available at: http://repositorio.ufpel.edu.br:8080/ handle/prefix/2955?mode=full. Access on: 14 Apr. 2020.

CISCAR, S. L.; GARCÍA, M. V. Fracciones: la relación parte-todo. Madrid: Síntesis, 1988.

COSTAS, F.; SELAU, B. On fundamentos de defectología and the development of Special Education teachers in Brazil. Educação, Porto Alegre, v. 41, 3, p. 401-10, Sept./Dec. 2018. DOI: http://dx.doi.org/10.15448/1981-2582.2018.3.31865

CROCHÍK, J. L.; FRELLER, C. C.; DIAS, M. A. L.; FEFFERMANN, M.; NASCIMENTO, R. B.; CASCO, R. Atitudes de professores em relação à educação inclusiva. Psicologia: Ciência e Profissão, Brasília, v. 29, n. 1, p. 40-59, Mar. 2009. Available at: http://pepsic.bvsalud. org/scielo.php?script=sci_arttext\&pid=S1414-98932009000100005\&lng=pt\&nrm=iso. Access on: 14 Apr. 2020.

DAFERMOS, M. Rethinking cultural-historical theory: a dialectical perspective to Vygotsky. Singapore: Springer, 2018. DOI: https://doi.org/10.1007/978-981-13-0191-9

DAFERMOS, M. Critical reflection on the reception of Vygotsky's theory in the international academic communities. In: SELAU, B.; CASTRO, R. F. (Org.). Cultural-historical approach: educational research indifferent contexts. Porto Alegre: Edipucrs, 2015. p. 19-38. Available at: http://cursos.unipampa.edu.br/cursos/ppgedu/files/2015/11/Cultural_HistoricalApproach_educacional-research-in-different-contexts.pdf. Access on: 14 Apr. 2020.

DAMIANI, M. F.; ROCHEFORT, R. S.; CASTRO, R. F.; DARIZ, M. R.; PINHEIRO, S. S. Discutindo pesquisas do tipo intervenção pedagógica. Cadernos de Educação, Pelotas, n. 45, p. 5767, May/Aug. 2013. Available at: https://periodicos.ufpel.edu.br/ojs2/index.php/caduc/ article/view/3822. Access on: 14 Apr. 2020.

DANIELS, H. An activity theory analysis of learning in and for inter-school work. Educação, Porto Alegre, v. 39, n. esp. (supl.), p. s24-s31, Dec. 2016. DOI: http://dx.doi. org/10.15448/1981-2582.2016.s.24319 
DRUZIAN, M. E. B. Jogos como recurso didático no ensino aprendizagem de frações. Vidya, Santa Maria, RS, v. 27, n. 1, p. 67-78, Jan./June. 2007. Available at: https://www. periodicos.unifra.br/index.php/VIDYA/article/view/350. Access on: 14 Apr. 2020.

ESTADO DO RIO GRANDE DO SUL. Secretaria da Educação. Lições do Rio Grande: Caderno Pedagógico de Matemática da 5a série do Ensino Fundamental. Porto Alegre: Total, 2009.

EVANS, P. Algumas implicações da obra de Vygotsky na educação especial. In: DANIELS, H. (Ed.). Vygotsky em foco: pressupostos e desdobramentos. São Paulo: Papirus, 2003. p. 69-89.

GIEST, H. Vygotsky's defectology: a misleading term for a great conception. Educação, Porto Alegre, v. 41, n. 3, p. 334-46, Sept./Dec. 2018. DOI: http://dx.doi. org/10.15448/1981-2582.2018.3.31725

GINDIS, B. Remediation through education: sociocultural theory and children with special needs. In: KOZULIN, A. et al. (Ed.). Vygotsky's educational theory in cultural context. New York: Cambridge University Press, 2003. p. 200-21.

GONZÁLEZ REY, F.; GOULART, D. M.; BEZERRA, M. S. Ação profissional e subjetividade: para além do conceito de intervenção profissional na psicologia. Educação, Porto Alegre, v. 39, n. esp. (supl.), p. s54-s65, Dec. 2016. DOI: http://dx.doi. org/10.15448/1981-2582.2016.s.24379

HATTON, C. Intellectual disabilities: classification, epidemiology and causes. In: EMERSON, E. et al. (Ed.). Clinical psychology and people with intellectual disabilities. 2. ed. Chicester: Wiley-Blackwell, 2012. p. 3-22.

KOHATSU, L. N. O uso do vídeo na pesquisa do tipo etnográfico: uma discussão sobre o método. Psicologia da Educação, São Paulo, n. 25, p. 55-74, 2007. Available at: http:// pepsic.bvsalud.org/scielo.php?script=sci_arttext\&pid=S1414-69752007000200004. Access on: 14 Apr. 2020.

LAITINEN, A.; SANNINO, A.; ENGESTRÖM, Y. From controlled experiments to formative interventions in studies of agency: methodological considerations. Educação, Porto Alegre, v. 39, n. esp. (supl.), p. s14-s23, Dec. 2016. DOI: http://dx.doi. org/10.15448/1981-2582.2016.s.24321

LIFELONG KINDERGARTEN DO MIT MEDIA LAB. SCRATCH SOFTWARE. [s.d.]. Available at: http://scratch.mit.edu. Access on: 18 Mar. 2016. 
LÜDKE, M.; ANDRÉ, M. A pesquisa em educação: abordagens qualitativas. São Paulo: EPU, 1986.

LURIA, A. S. Speech and the development of mental processes in the child. Hazmondsworth, UK: Penguim Books, 1971.

LURIA, A. S. Higher cortical functions in man. New York: Basic Books, 1966.

MANTOAN, M. T. E. Inclusão, diferença e deficiência: sentidos, deslocamentos, proposições. Inclusão Social, Brasília, v. 10, n. 2, p. 37-46, Jan./June 2017. Available at: http://revista. ibict.br/inclusao/article/view/4030/3366. Access on: 14 Apr. 2020.

MELETTI, S.; BUENO, J. A escolarização de alunos com deficiência intelectual: análise dos indicadores nacionais brasileiros. In: MELETTI, S.; BUENO, J. (Org.). Políticas públicas, escolarização de alunos com deficiência e pesquisa educacional. Araraquara, SP: J\&M, 2013. p. 75-86.

MORAES, R. Uma tempestade de luz: a compreensão possibilitada pela análise textual discursiva. Ciência \& Educação, Bauru, SP, v. 9, n. 2, p. 191-211, 2003. Available at: http:// www.scielo.br/scielo.php?pid=S1516-73132003000200004\&script=sci_abstract\&tlng=pt. Access on: 14 Apr. 2020.

MUSIS, C. R.; CARVALHO, S. P. Representações sociais de professores acerca do aluno com deficiência: a prática educacional e o ideal do ajuste à normalidade. Educação \& Sociedade, Campinas, SP, v. 31, n. 110, p. 201-17, jan./mar. 2010. DOI: http://dx.doi. org/10.1590/s0101-73302010000100011

NUNES, T.; BRYANT, P. Crianças fazendo matemática. Porto Alegre: Artes Médicas, 1997.

NUNES, T. et al. Educação matemática: números e operações numéricas. São Paulo: Cortez, 2005.

PASSERINO, L.; COMA, T.; BALDASSARRI, S. Interacción tangible para la Compensación Social de procesos mediados en niños con diversidad funcional. Educação, Porto Alegre, v. 41, n. 3, p. 362-73, Sept./Dec. 2018. DOI: http://dx.doi.org/10.15448/1981-2582.2018.3.31732

PEREIRA, C. A. Estudando as frações. 2011. 26f. Course Conclusion Paper (Mathematical Specialization, Media and Didactics) - Federal University of Rio Grande do Sul (UFRGS), Porto Alegre, 2011. Available at: https://lume.ufrgs.br/handle/10183/31585. Access on: 14 Apr. 2020. 
PINHEIRO, S. N. S. O jogo com regras explícitas pode ser um instrumento para o sucesso de estudantes com história de fracasso escolar? 2014. 219f. Thesis (Doctorate Degree in Education) - Federal University of Pelotas (UFPel), Pelotas, RS, 2014. Available at: http:// bdtd.ibict.br/vufind/Record/UFPL_0d6f6c63559e77f46e58687a8eadb59b. Access on: 14 Apr. 2020.

QUEROL, P.; JACKSON FILHO, J. M.; CASSANDRE, M. P. Change Laboratory: uma proposta metodológica para pesquisa e desenvolvimento da aprendizagem organizacional. Administração: Ensino e Pesquisa, Rio de Janeiro, v. 12, n. 4, p. 609-40, Oct./Dec. 2011. DOI: https://doi.org/10.13058/raep.2011.v12n4.143

ROCHEFORT, R. S. Ensinar a ensinar... Aprender para ensinar! As aprendizagens na formação inicial em Educação Física nas perspectivas das Teorias Histórico-Cultural e da Atividade. 2012. 348f. Thesis (Doctorate Degree in Education) - Federal University of Pelotas (UFPel), Pelotas, RS, 2012. Available at: http://guaiaca.ufpel.edu.br/handle/123456789/1683. Access on: 14 Apr. 2020.

RODRIGUES, S. P. A aprendizagem do conceito científico de fração por alunos com deficiência intelectual: os resultados de uma intervenção. 2017. Dissertation (Master's in Education) - Federal University of Pampa (UNIPAMPA), Jaguarão, SC, 2017. Available at: http://dspace.unipampa.edu.br:8080/jspui/handle/riu/2557. Access on: 14 Apr. 2020.

SANNINO, A. Counteracting the stigma of homelessness: the finnish housing first strategy as educational work. Educação, Porto Alegre, v. 41, n. 3, p. 385-392, Sept./Dec. 2018. DOI: http://dx.doi.org/10.15448/1981-2582.2018.3.32025

SANNINO, A.; SUTTER, B. Cultural-historical activity theory and interventionist methodology: classical legacy and contemporary developments. Theory \& Psychology, v. 21, n. 5, p. 557-70, Oct. 2011. DOI: https://doi.org/10.1177/0959354311414969

STETSENKO, A. The transformative mind: expanding Vygotsky's approach to development and education. New York: Cambridge University Press, 2017.

STETSENKO, A. Vygotsky's theory of method and philosophy of practice: implications for trans/formative methodology. Educação, Porto Alegre, v. 39, n. esp. (supl.), p. s32-s41, Dec. 2016. DOI: http://dx.doi.org/10.15448/1981-2582.2016.s.24385

STETSENKO, A.; SELAU, B. Vygotsky's approach to disability in the context of contemporary debates and challenges: charting the next steps. Educação, Porto Alegre, v. 41, n. 3, 31524, Sept./Dec. 2018. DOI: http://dx.doi.org/10.15448/1981-2582.2018.3.32668 
TEIXEIRA, A. C.; FURINI, C. S.; CAIMI, F. E. A equilibração majorante em crianças de educação infantil: um estudo de caso. Revista da FAEEBA - Educação e Contemporaneidade, Salvador, BA, v. 27, n. 53, p. 251-70, Sept./Dec. 2018. DOI: http://dx.doi.org/10.21879/ faeeba2358-0194.2018.v27.n53.p251-270

TOLEDO, M.; TOLEDO, M. Didática da matemática: como dois e dois: a construção da matemática. São Paulo: FTD, 2010.

TOOMELA, A. What are higher psychological functions? Integrative Psychological and Behavioral Science, v. 50, p. 91-121, 2016. Available at: https://link.springer.com/ article/10.1007\%2Fs12124-015-9328-0. Access on: 14 Apr. 2020.

TOOMELA, A. Vygotskian (but only partly Vygotsky's) understanding of special education. Educação, Porto Alegre, v. 41, 3, p. 347-61, 2018. DOI: http://dx.doi. org/10.15448/1981-2582.2018.3.31795

VEGGETTI, M. S. Becoming a person through innovative inclusive education. Educação, Porto Alegre, v. 41, n. 3, 393-400, Sept./Dec. 2018. DOI: http://dx.doi. org/10.15448/1981-2582.2018.3.31755

VYGOTSKY, L. S. The collected works: problems of general psychology. Moscow: Pedagogika, 1983a.

VYGOTSKY, L. S. Introduction to E. K. Gracheva's book. In: The collected works: the fundamental problems of defectology. Moscow: Pedagogika, 1983b. p. 222-30.

VYGOTSKY, L. S. The fundamental problems of defectology. In: The collected works: the fundamentals of defectology. Moscow: Pedagogika, 1983c. p. 6-33.

VYGOTSKY, L. S. The collective as a factor in the development of the abnormal child. In: The collected works: the fundamentals of defectology. Moscow: Pedagogika, 1983d. p. 196-218.

VYGOTSKY, L. S. Compensatory processes in the development of the retarded child. In: The collected works: the fundamentals of defectology. Moscow: Pedagogika, 1983e. p. 115-36.

VYGOTSKY, L. S. The problem of mental retardation. In: The collected works: the fundamentals of defectology. Moscow: Pedagogika, 1983f. p. 231-56.

VYGOTSKY, L. S. The development of scientific concepts in childhood. In: The collected works: problems of general psychology. Moscow: Pedagogika, 1982a. p. 184-294. 
VYGOTSKY, L. S. The historical meaning of the crisis in psychology. In: The collected works: problems of the theory and history of psychology. Moscow: Pedagogika, 1982b. p. 291-436.

WERTSCH, J. V. Mediation. In: DANIELS, H.; COLE, M.; J. WERTSCH, J. (Ed.). The Cambridge Companion to Vygotsky. New York: Cambridge University Press, 2007. p. 178-92.

\section{About the authors:}

Bento Selau: Doctorate in Education from the Federal University of Pelotas (UFPel). Professor of the Graduate Program in Education at the Federal University of Pampa (Unipampa). Research productivity fellowship of the National Council for Scientific and Technological Development (CNPq). E-mail: bentoselau@gmail.com, Orcid: http://orcid.org/0000-0002-5792-0284

Sastria de Paula Rodrigues: Master's Degree in Education from the Federal University of Pampa (Unipampa). Educational Affairs Technician at the Sul-RioGrandense Federal Institute for Science, Education, and Technology (IFSul). E-mail: sastriapr@pelotas.ifsul.edu.br, Orcid: http://orcid.org/0000-0003-4108-7782

Fabiane Costas: Doctorate in Education from the Federal University of Rio Grande do Sul (UFRGS). Professor of the Graduate Program in Education at the Federal University of Santa Maria (UFSM). E-mail: fabicostas@gmail.com, Orcid: http://orcid.org/0000-0003-3698-2782

Aliciene Cordeiro: Doctorate in Education from the Pontifical Catholic University of São Paulo (PUC-SP). Professor of the Graduate Program in Education at the University of the Joinville Region (Univille). E-mail: aliciene_machado@hotmail.com,Orcid: http://orcid.org/0000-0001-6778-5285

\section{Received on November 21st, 2019.} Approved on December 24th, 2019. 
